\section{IIASA regains US support}

\section{Munich}

IN keeping with changing East-West relations, the United States has promised to restore its support for the International Institute for Applied Systems Analysis (IIASA). In a letter from White House science adviser D. Allen Bromley dated 5 January, the US government promises to resume full cooperation with IIASA, from which it had withdrawn in 1982 following suspicions that the institute contained Soviet spies.

IIASA was established in 1972 as an international think-tank at Laxenburg, near Vienna, by the United States, the Soviet Union and ten other countries. The institute brings in researchers from all its member countries, now 16 , to study global problems such as forest decline and transboundary pollution.

Bromley set two conditions for US government reentry into IIASA: that the institute focus more on environment and climate change, and that it consider changing its name to reflect the new programme. IIASA spokesman Jean-Guy Carrier said the conditions will be easy to meet and that IIASA researchers were overjoyed by the change of mind.

Former Secretary of State George Shultz said in 1984 that withdrawal from IIASA was motivated by a desire to invest more in bilateral, rather than multilateral, research. But the real reasons had more to do with concern that IIASA was being used for Soviet intelligence gathering.

Support from the National Science Foundation was resumed in 1987 but the US government remained unwilling to help. Instead, the American Academy of Arts and Sciences, IIASA's official US 'partner' organization, pieced together the US contribution with donations from charitable foundations.

Several US senators urged the administration to change its view, and there was a 'concerted effort' by academies of science in the Soviet Union and Eastern European countries to persuade the United States to renew its support for IIASA, said Carrier. If the turnabout had not come, ousting the United States from the organization was a "serious possibility", he said.

But the dramatic changes in Eastern Europe probably made the biggest difference in changing the US position. Carrier said that the reorganized Czech State Commission for Science, Technology and the Environment has invited IIASA to present its ideas on air and water pollution in Czechoslovakia in March. It is the first invitation to IIASA by that country in $\mathbf{1 6}$ years, he said. East Germany has also invited IIASA to present a news conference in East Berlin on acid rain in April, another first.

Steven Dickman

\title{
New drive on car pollution
}

\section{Paris}

FRENCH government and industry last week announced their intention to build an energy-efficient and non-polluting 'green' car.

The logic behind the announcement is simple: last year, transport consumed as much energy as French industry and now burns 60 per cent of the nation's oil imports. Thirty per cent of all carbon dioxide emissions, 70 per cent of carbon monoxide and 10 per cent of sulphur dioxide emissions come from transport. And the trend is increasing, despite a reduction in the size of engines since the 1970 s petrol crisis. Over the past 15 years, the urban use of the motor car has increased by 60 per cent.

Backing for the green car comes in a joint protocol signed by three government ministries (research, industry and transport) and car manufacturers Peugeot SA and Renault. Over the next five years, the two companies promise to triple their research effort, while the government will encourage the state research organizations to play their part in "adapting the motor car to the environment".

Peugeot and Renault, usually thought of as competitors, will invest FF1,200 million ( $\$ 190$ million) over the next five years in joint and separate ventures to make existing engines cleaner, while looking for new types of engine.

High on the list is the two-stroke, which produces few nitrogen oxides but is not very efficient. Gas turbines, possibly burning hydrogen fuels, will also be tried. Electric cars are already being produced, but they have a daily maximum range of $100 \mathrm{~km}$. To replace the small family petrol-engined car, they would need to have a range more like $500 \mathrm{~km}$ before recharging. Research is to be intensified into new kinds of battery. The manufacturers have given themselves five years for pilot studies and three to four years to build a prototype.

Some FF500 million will go towards

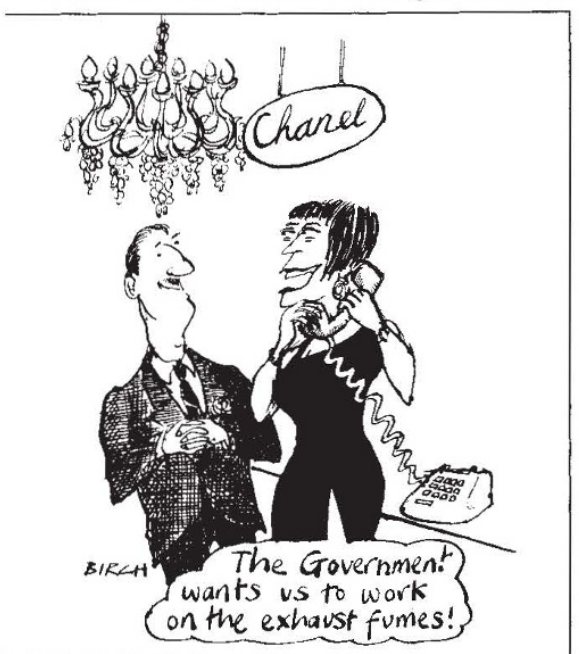

improving the energy-efficiency of existing cars, while reducing levels of pollution in line with European Communities regulations agreed last June. As more than half of all car journeys are less than three $\mathrm{km}$ - when engines are cold and therefore much less efficient - new engines are likely to incorporate some kind of preheating device.

Peter Coles

\section{ENERGY:CALIFORNIA}

\section{Utilities see the green light}

\section{San Francisco}

California's electric-power companies are making friends with their long-time enemies in environmental and consumerprotection groups and discovering the surprising fact that there may be money in not generating electricity - or at least no more than is really needed.

In a new scheme proposed last week, cash rewards would be paid to consumers adopting energy-efficient technologies. The utilities see energy efficiency benefiting them principally because they will have to invest less capital in new power plants and purchase less electricity from alternate sources.

The plan brings together most of California's big electric-power companies, the Natural Resources Defense Council and the consumer organization Toward Utility Rate Normalization (TURN), as well as industry trade associations and government agencies.

In submitting the plan to the California
Public Utilities Commission (CPUC) for consideration, backers claimed that a $\$ 500$-million investment over the next two years would result in savings of more than $\$ 1,000$ million.

Rewards would go both to the small and the large: Pacific Gas and Electric, the largest US electric utility, talks of rebates of up to $\$ 100$ for the purchase of energyefficient refrigerators and air conditioners, $\$ 15,000$ for commercial customers installing more efficient equipment and $\$ 300,000$ for large industrial customers building plants using the latest energysaving technology.

Participants stress that the plan is not yet finalized. Each utility has outlined different means of achieving its energyconservation goals and redistributing the cost savings to shareholders and ratepayers. By the end of March, CPUC is expected to establish several test studies to determine which are more efficient.

Robert Buderi 